\title{
Study on teaching quality of music teachers in colleges under quality education background
}

\author{
$\mathrm{Na}$ Wang \\ Music College \\ Beihua University \\ Jilin 132013, China
}

\begin{abstract}
Aesthetic education is the important component of the character building education, but music education is an important means to implement character building education, train more university students with quality of aesthetic education today when could be recommending character building education in a more cost-effective manner, the music teacher's quality is the key point. The main visual angle of this text is in term of training university student's character building education, canvass the teaching quality which the music teacher of the university should possess under the character building education background.
\end{abstract}

Keywords- Aesthetic education; Teaching quality; Ability

\section{INTRODUCTION}

21 st century is the period that China makes great efforts to advance character building education in an all-round way. It is deepened that the ones that are accompanied by educational reform are gradual, the whole society pays more and more attention to students too, especially university students' character building education. If you want to do a good job of university student's character building education, should strengthen university's teacher's teaching quality first, because quality and level educated depend on the teacher's quality and level.

Aesthetic education, educate aesthetically, it follows the basic principle of aesthetics, according to the objective law of pedagogy, through to the intersection of an and American social the intersection of life and American, feeling, appreciation, displaying and creating of natural beauty, train people's estheticism, make people establish the correct aesthetic standard, develop healthy aesthetic temperament and interest. The educational work of our country is taking character building education as prerequisite at present. Character building education is in order to overall qualities of improving students in an all-round way as the education of the goal. The proposition of character building education is an evidence of to policy for education of overall development and promotion, it relies mainly on student, the education that pay attention to the development of individual character and the creativity trains, it is the universal education facing all students too at the same time. It includes thought quality, cultural dynamics, psychological quality, body constitution, quality of working. Any period emphasized the character building education to university students even more than in the past in the university at present, and the one that train university student Germany, intelligent, body, the U.S.A. and China" Aesthetic education" It is one of the music teacher's important duties. Music lesson is an important field of people literature, it is one of the main routes to implement aesthetic education. The main task of aesthetic education is to train student's correct aesthetic standards and improve them to appreciate beauty, display beauty, create beautiful ability. It is the most basic properties of music education to be aesthetic, in the aesthetic education of tile music, the psychology that the focal point is of training students to like to be beautiful, should distinguish beauty uglily. The cultivation of the psychology not merely concerns the question of the aesthetic conceptions to like to be beautiful, concern questions such as moral concept, outlook on life, values, etc.. Students have a correct understanding and appreciation on U.S.A. through educating aesthetically, and have noble morals sentiment and aesthetics temperament and interest. Students through educating training are aim to pursuit the desire of for beauty and creating beautiful ability aesthetically. The aesthetic education of the intact meaning is through grasping and using" .The beautiful law" .In with transformation naturally, transform mankind of society, practice in the every educational work that the activity is closely related with, through certain behavior, realize the goal of certain education. Aesthetic education is it is to bring up people overall for harmonious development, last Germany, intelligently, body all-round developing builders and the means important of successor socialist. Aesthetic education includes art to educate, as to other subjects, artistic discipline is in the form of having substantial aesthetic feeling content, vivid aesthetic feeling, to realize that bring home to one's heart, gladden the heart and refresh the mind, shake the aesthetic educational function of soul. As the music education in artistic discipline, regard through the ages colorful music as the content, appreciate and sing, play the activity for the content with living the intersection of wave and vivid flexible music, give play to it to foster lofty though! morals, mould noble sentiment, inspire intelligence, improve one's own overall qualities in an all-round way, promote the monobasic functions that grow up healthy and sound in all respects of teenagers. Therefore music education is one of the main content and route to implement aesthetic education. Music teacher, as the implementer of music education's one's own quality and training, must play a decisive role. If so, the music teacher wants to afford to bear the qualified music teacher of character building education as one, professional 
ethics training, improving one's own professional quality in an all-round way of soon constant completion, there should be noble character, it is learned and versatile to also want. bring in constant renewal in and improve the educational idea, initiative spirit, creativity and ability to organize rich in teaching.

In the music teaching of the university, every music teacher should pay attention to the artistry of teaching of music, study classroom instruct/on art while following one's own law of music art according to tile characteristic of every course of the music, music theory of letting students know the skill of the music, understand, having a taste of the artistic intention of the works. University's music teacher can be divided into teacher, technological theory lesson teacher, music skill lesson teacher of basic theory lesson according to taught. The lesson teaching of the basic theory is theory and foundation of all course teaching of music, the lesson teaching of the basic theory must be based on the fact that students have certain practice moves about, fully experiences the music. In teaching, know, consummate application basic theory knowledge that the teacher should instruct students how to know progressively while the music is practiced. In addition, the knowledge of basic theory has very strong systematicness and science, the music teacher should analyze in depth, understand the content of courses, know the concept, term, symbol of theory knowledge involved in the teaching material conscientiously, unity of explaining wanting, and keep unanimity in every subject teaching. The technological theory lesson is the theory and technical course that combines, its teaching is to carry on technical creation and appreciation on the basis of basic theory lesson, as the intersection of specialized course and Mr. of Jiao person Shi deal with, compose music harmony in the theory, reply transfer, musical form, the intersection of song and the intersection of person who make, orchestrate and the intersection of knowledge and the intersection of skill and sufficient understanding and master, get hold of the key of every subject teaching at the same time. The music skill lesson mainly includes vocal music lesson, instrumental music lesson and solfeggio lesson. The music is art of the sound, the grasping of skill lesson serves for displaying the music. The vocal music lesson includes to grasping and two respects of manifestation to the music singing the knowledge, skill. And two respects to the manifestation of the music that instrumental music lesson including play knowledge of various musical instruments, skill etc. is mastered.

\section{FUTURE DEVELOPING TREND OF TEACHER'S TEACHING QUALITY OF UNIVERSITY'S MUSIC}

The music teacher's quality of ethics of the teaching profession is the first place. The music teacher should have noble professional ethics. The so-called professional ethics, professional people, ethical principle and code of conduct that should follow while carrying on the job and moving about that refer to engaged in sure properly. The music teacher should possess outstanding job quality, because teacher's personal ethical quality is strong education factor and educational strength. As a music teacher of university, should have firm political orientation, should have firm faith of communism, love the educational work of music, loyal music educational undertaking, dedicate oneself to the music educational undertaking, it should be willing to be lonely, sweet ladder, have lofty devotion and unselfish spirit of utter devotion. In the real work, love students for being the concrete behavior which love educational undertaking, it is key content of the ethics of the teaching profession to love students, it is the important educational principle proved by a lot of outstanding teachers, successful experience too. An outstanding music teacher is sure to establish a good teacherstudent relationship with students, the enthusiasm by having one's bosom filled with, the high-level sense of duty, not only strict with students but also care about, respect, believe in students, strive to reach respecting to believe in with that of strict requirement organically and unify. The music teacher should love the teacher for the teacher's collective at the same time, respect the parents of student, handling well between a teacher, the teacher and relation between the parents. The music teacher should be strict with oneself at the same time, set an example, a model for others, make the example for students. So, the music teacher wants the moral training of constant enhancement, constant improvement one's own ideological and ethical standards.

Teacher's professional knowledge of university's music is its primary condition that finishes a duty job with high quality. There should be systematic music discipline professional knowledge at first. The professional' knowledge of discipline is teacher's

professional theory knowledge corresponding to subject taught, as to music teacher, require its understanding that the professional knowledge which teach subject have sturdy foundation and deep, know the basic theories, rudimentary knowledge and corresponding skill of the department taught systematically, familiar with history and current situation of this discipline, find out about its newest scientific findings and development trend, understand a discipline learning method and research approach, can impart with the skill to students by way of suring, and understanding and acceptance that can make students real. Secondly there should be solid education professional knowledge. If you want to become a qualified music teacher, must have education, psychology scientific knowledge training. It requires the teacher to understand thoroughly and teach the discipline professional knowledge of subject, as well as understand general education and gain knowledge, such as education, psychological basic theories, history of education, educational psychology, educational managerialics, relatively educating etc.. Music Mr. systematic science grasp educational professional knowledge only, could the speciality taught toward oneself accomplishes to do a job with skill and ease, can be chosen the rational teaching method to different contents, and then promote the development of student, strengthen students' character building education. The intersection of music and Mr. pays attention to the accumulation of one's own practicality knowledge and experience in actual work in addition, it is the outstanding music teacher's experience 
characteristic to practice knowledge in solid grasping and skilled application teaching.

University's music teacher should be learned and versatile have wide scientific cultural knowledge, understand the educational teaching law. In the face of the highly split up as well as highly comprehensive characteristic of scientific development, require the music teacher to have abundant knowledge to store, the range of knowledge should be wide, big, rich, deep, want extensive dabbling every discipline knowledge, train and develop one's own interests in many aspects, by" study all the life" Ideology it is one's own reasonable construct knowledge structure,

It can spend by teaching of music. Strengthen the cultural and educational intension of music discipline in teaching, emphasize the mutual infiltration between every discipline, teacher's wide knowledge of the music can make the teaching of music launch in the pluralistic background. Meanwhile, the music education in new period requires the music teacher to understand the educational law promptly, also study the teaching method, use knowledge of science of education such as pedagogy, psychology, as in order to builder and developer of course, make one's own music rich and colorful in teaching, promote the overall development of student's overall qualities and improve. Meanwhile, the music teacher is regarded as one of the main force of contemporary quality educational reform and development, must and educate the new achievement known according to the needs of requirement of times and educational development, form the scientific education idea, this require music Mr. have one brand-new understanding to music education with relation, the intersection of music education and relation with people's physical and psychological development of social development, and establish scientific education values, student's view, teaching view and gate of the quality monitoring of teaching on this basis.

Music teacher, as the university is besides possessing the modem's basic capacity quality, this historical mission of better completion character building education that want, must also possess and engaged in teacher's job of tile music peculiarly from teaching ability. Teaching ability is a basic quality which music teachers must possess, teaching ability is through the effective means, the ability of accomplishing the task of teaching that give full play to the role of the teacher's leading role and students' subject in teaching, the ability the intersection of oneself and good singing play what competence can substitute absolutely not. This is that we often say ' A good music educationist can be an outstanding singer or accomplished performer but an outstanding singer or accomplished performer may not be a good music educationist" . University's music teacher's teaching ability is many kinds of ability such as a synthesis, it including knowledge, skill, managing, analyzing and judging, this kind of ability is that exercise came out in long-term teaching practice. It is the ability of language expression at first and analyzes judgment. The language is that the teacher teaches knowledge and links up the main carriers and tools of the contacts with students to students. Czech educationist praises the American knob Sri Lankan for saying" the teacher's mouth has been a source, can produce the brook of knowledge from there. ' The ability of language expression is teacher's most important ability accomplishment, it is the teacher that is engaged in education, teaching and scientific research, taught important tool and essential condition of knowledge and skill to students. As the music teacher, only know the skill of the music is incompetent, so must possess the ability to express of the language, strengthen the training in ability of language expression voluntarily by oneself at ordinary times, strive to make the oral language to express popularly, succinctly, vividly, lifelikely; The written language expresses the view accurately, read smoothly. In addition, the music teacher should discover the problems, analyze and judge the problem, ability to solve problem, this kind of ability is strong guarantee of accomplishing the task of teaching. Germany famous orff, educationist of music, through experiment, observation, analyze, have created the education system of one orrf of music. Need to accumulate the knowledge experiences of various fields, correct analysis and judgment and solving the problem as university's music teacher. Secondly it is the classroom that organizes teaching and uses the education skill ability of present information. Quality of a class, can achieve the goal of teaching, finish the set teaching goal, it guarantees the measure is that the teacher will good at organizing teaching. Organize teaching to be a very important link in the teaching of music. The music teacher should be according to the request of train objective during the course of preparing before music lesson, on the basis of studying the tutoring system characteristic, specify music teaching purpose task, content of music teaching, music teaching means. Music Mr. launch stage want, cause student study interest in lesson, stimulate the intersection of student and initiative, enthusiasm of study, and study the purpose, it makes students experience, understand teaching material that teacher explains the music through demonstrating, form image in studying the content, through practising making students' knowledge, skill deepened, developed and improved repeatedly. The music teacher should analyze, summarize the phased result to the teaching course at the summary stage of the lesson. With the function in the field of educational teaching, the modem science and technology have changed the requirements for teacher's quality of teacher's job. This requires music teacher not merely wants to possess to utilize modern information technology to obtain the ability of the most advanced knowledge, and should learn to use modem information technology to carry on teaching and guide the ability of students. Music Mr. must understand the intersection of multimedia and computer and the intersection of network and the intersection of teaching and form of expression of media and commit form, know the basic working technique, learn the making of different coursewares, in order to meet demands of teaching of music. The third is the teaching creativity. The teacher is known as the artist of soul, the teaching of university's music teacher has been already following the law, while creating tile law constantly. The socalled creativity refers to development and innovation on the basis of universal law, the ones that are for the detailed conditions and make are favorable to student's study measure, 
its characteristic is with strong points, attractive, can arouse students' thinking.

\section{CONCLUSIONS}

At present, of our country tile intersection of music and as to have certain disparity with other high-speed teaching body of discipline of development quality of teaching body of university, teacher should carry on the music constantly" The self-perfection",Improve professional skill. One of the main tasks of the institution of higher learning is just engaged in scientific research.The characteristic of music education and scientific research is objectivity, theory and original idea. It is to the summary of educational practice, the development of music education proposes imagining, thus promote constant completion and progress of music education and make music education give play to the role of its oneself better in the course of implementing character building educationEnter, one that is with character building education energetic to recommend, people already careful to know, get important function on character building education, Mr. of music, $21^{\text {st }}$ century, the requirements for job quality and personal training of the music teacher are higher and higher. As the music teacher, only comply with the trend of development of era, follow the era paces closely, in the real work and one's own work is combined, improve one's own overall qualities in an all-round way, only constant study, constant self-perfection, could undertake the important task entrusted in era, could become an outstanding music teacher.

\section{REFERENCES}

[1] Cao Li, "Discipline pedagogy of the music," Capital Normal University Publishing House

[2] Guo YuQing, "Music aesthetics educates several question discussions," the 6th issue of 2009

[3] Jiang Dan, "Retrospect and prospect of music educational practice of ordinary higher learning school," the third issue in 2007

[4] Cao Li, "Ordinary school music pedagogy," The educational publishing house of Shanghai, 2006 